\title{
HUBUNGAN PENGETAHUAN DAN SIKAP DENGAN TINDAKAN PENCEGAHAN PENYAKIT INFEKSI MENULAR SEKSUAL PADA ANAK BUAH KAPAL DI PELABUHAN BELAWAN
}

\author{
Isroni Azhari Siregar ${ }^{1}$, Masryna Siagian², Herbert Wau \\ 1,2,3 Universitas Prima Indonesia Jl Sekip Simp. Sikambing, Medan, Indonesia \\ Email: ariazhari426@gmail.com
}

DOI : https://doi.org/10.35451/jkk.v2i1.231

\begin{abstract}
Sexually transmitted infections are one of the channel infections preproduction is transmitted through sexual contact. $A B K$ is called the highrisk community or men with riskhigh sxually transmitted infections disease. The purpose of this study was to determine the relationship of knowledge and attitudes with the prevention of sexually transmitted infections to the Boatmen ( $A B K$ ) in the Port of Belawan. This research is a type of research that uses analytic survey with cross sectional research design. Data collection is done through primary data using questionnaires and secondary data using other supporting data. Data analysis using bivariate analysis using frequency distribution and multivariate analysis using chi-square test. The results obtained that there is a relationship of knowledge with the prevention of sexually transmitted infections in $A B K$ in Belawan Harbor in 2019 ( $p=0.002<0.05$ ), and there is a relationship between attitude and prevention of sexually transmitted infections in $A B K$ in Belawan Port in 2019 ( $p$ value $=0,000<0.05$ ). Therefore, it is expected that $A B K$ will increase their knowledge and attention regarding sexually transmitted infections, namely by attending counseling from health workers, reading books and magazines related to sexually transmitted infections and through other media access so that prevention efforts are more optimal, so as to avoid themselves from contracting sexually transmitted infections.
\end{abstract}

Keywords: Knowledge, Attitudes, Sexually Transmitted Infectious Diseases

\section{Pendahuluan}

Infeksi Menular Seksual (IMS) merupakan salah satu Infeksi Saluran Reproduksi (ISR) yang ditularkan melalui hubungan kelamin.Infeksi saluran

reproduksi merupakan infeksi yang disebabkan oleh masuk dan berkembang biaknya kuman penyebab infeksi ke dalam saluran reproduksi. Kuman penyebab infeksi tersebut dapat berupa jamur, virus, dan parasit. Salah satu Infeksi menular seksual yaitu Human Immunodeficiency Virus (HIV)/ Acquired Immune Deficiency Syndrome (AIDS) (Ardhiyanti, 2015).

Infeksi Menular Seksual (IMS) merupakan salah satu pintu masuk HIV.Total kasus IMS yang ditangani pada tahun 2018 adalah 140.803 kasus dari 430 layanan IMS.Jumlah kasus IMS terbanyak adalah di tubuh vagina 
(klinis) 20.962 dan Servictis / procitis (lab) 33.205 (Kemenkes,2017)

Penyakit kelamin (veneral disease) sudah lama dikenal dan beberapa

diantaranya sangat popular di Indonesia yaitu sifilis dan gonorhea. Peningkatan insiden Infeksi Menular Seksual (IMS) dan penyebarannya di seluruh dunia tidak dapat diperkirakan secara tepat. Setiap tahun beberapa juta kasus baru beserta komplikasi medisnya antara lain kemandulan, kecacatan, gangguan kehamilan, gangguan pertumbuhan, kanker bahkan juga kematian memerlukan penanggulangan, sehingga hal ini akan meningkatkan biaya kesehatan. Selain itu pola infeksi juga mengalami perubahan, misalnya infeksi lamidia, Herpes genital, dan Kondiloma akuminata di beberapa negara cenderung meningkat dibandingkan dengan uretritis gonore dan sifilis (Fahmi dkk, 2014)

IMS termasuk diantara 5 kategori penyakit dewasa yang mencari pelayanan kesehatan dan memiliki dampak besar pada kesehatan seksual dan reproduksi. Angka kejadian paling tinggi tercatat di Asia Selatan dan Asia Tenggara, diikuti Afrika bagian Sahara, Amerika Latin, dan Karibean.Prevalensi IMS di negara berkembang jauh lebih tinggi dibandingkan dengan di negara maju. Pada perempuan hamil di dunia, angka kejadian gonore $10-15$ kali lebih tinggi, infeksi klamidia 2 - 3 kali lebih tinggi, dan sifilis 10 - 100 kali lebih tinggi jika dibandingkan dengan angka kejadiannya pada perempuan hamil di negara industri. Pada usia remaja (15 24 tahun) merupakan 25\% dari semua populasi yang aktif secara seksual, memberikan kontribusi hampir 50\% dari semua kasus PMS baru yang didapat. Kasus-kasus IMS yang terdeteksi hanya menggambarkan $50 \% \quad-\quad 80 \%$ dari semua kasus IMS yang ada di Amerika. Ini

keterbatasan "screening" dan rendahnya pemberitaan akan IMS (Sarwono, 2011)

Kasus HIV-AIDS di Sumatera Utara sampai dengan Juni 2017 adalah 8.399 kasus, dengan perincian HIV 3478 kasus dan AIDS 4.921 kasus, dan berada pada ranking ke-7 dari 33 Provinsi di Indonesia. Angka prevalensi HIV-AIDS

Sumut adalah 28,97 per 100.000 penduduk, artinya adalah setiap 100.000 penduduk di Sumatera Utara terdapat 29 orang yang menderita HIVAIDS

(KPA

Sumut, 2017).

Setelah Jakarta dan Surabaya Medan merupakan salah satu kota metropolitan terbesar di Indonesia. Jumlah penduduknya banyak dan sebagian penduduknya ada yang memiliki perilaku seksual berisiko. Data yang dihasilkan dari KPA Kota Medan menunjukkan bahwa pada tahun 2015 jumlah lakilaki di kota Medan ada 1878 terkait IMS (KPA Medan, 2015) dan berdasarakan data yang tercatat di PKBI ada 301 laki-laki yang positif terkena IMS di kota Medan.

Berdasarkan kasus Infeksi Menular Seksual Dinas Kesehatan Kota Medan tahun 2015-2017. Pada tahun 2015 sebanyak 426 jiwa tahun 2016 sebanyak dan pada tahun 2017 sebanyak 556 jiwa. Dinas Kesehatan Kota Medan 2018. Pada tahun 2015 sebanyak 5\% ABK positif IMS dari 696 ABK, pada tahun 2016 ABK yang positif $17 \%$ ABK dari 694 ABK pada tahun 2017 sebanyak $14 \%$ ABK positif dari 670.(KKP kelas I Medan, 2018)

Pada tahun 2015 sebanyak 1 ABK positif IMS dari 234 ABK.Pada tahun 2016 sebanyak 8 ABK positif IMS 
dari 3.405 ABK.Pada tahun 2017 sebanyak

ABK positif IMS dari 2.454 ABK (KKP kelas I Tanjung Priok, 2018).

Berbagai faktor diperkirakan merupakan faktor risiko kejadian IMS. Telaah beberapa jurnal membuktikan bahwa pola perilaku seksual memiliki hubungan dengan kejadian IMS.Salah satu prediktor yang paling kuat adalah pengetahuan. Hasil penelitian Kusnan, menemukan bahwa ada hubungan antara pengetahuan tentang penyakit IMS dengan kejadian IMS $(p=0,001)$. Peran media sebagai penyalur informasi juga diharapkan menghasilkan perubahan perilaku dan peningkatan pengetahuan. Media informasi mengandung nilai manfaat, merupakan salah satu faktor yang memengaruhi pola pikir dan perilaku. Hasil penelitian Amiruddin, dkk. menunjukkan bahwa ada hubungan peran media dengan hygiene perorangan terhadap pencegahan infeksi menular seksual pada anak jalanan di Kota Makassar $(p=0,000)$. Beberapa faktor lainnya yang telah disebutkan dalam tujuan penelitian seperti status ekonomi, akses pelayanan kesehatan, dan peran petugas kesehatan juga diduga berhubungan dengan kejadian IMS.

Nari (2015), dengan judul penelitian Analisis Faktor-Faktor yang Berhubungan dengan Kejadian IMS padaRemaja di Klinik IMS Puskesmas Rijali dan Passo Kota Ambon.Hasil penelitian menunjukkan bahwa bivariat umur

dan religiusitas berhubungan dengan perilaku seks berisiko sedangkan perilaku seks berisoko dan riwayat IMS berhubungan dengan kejadian IMS. Hasil uji regresi logistic menunjukan riwayat IMS merupakan variabel yang paling berpengaruh terhadap kejadian IMS dimana remaja yang mempunyai riwayat IMS, kemungkinan untuk berisiko terinfeksi IMS 31.4 kali lebih besar dibandingkan denganremaja yang tidak mempunyai riwayat IMS.

Puspita (2017), dengan judul penelitian Analisis Faktor Yang Berhubungan Dengan Kejadian Infeksi Menular Seksual Pada Wanita Pekerja Seksual Analisis Faktor Yang Berhubungan Dengan Kejadian Infeksi Menular Seksual. Hasil penelitian menunjukkan bahwa ada hubungan yang bermakna antara umur $(p=0,012 ;$ or $=3.6)$, status pernikahan $\quad(p=0,035 ; \quad O R=3.1)$, penggunaan kondom $(p=0.001$; $\mathrm{OR}=5.5$ ). Hasil analisis multivariat menunjukkan bahwa penggunaan kondom paling dominan berhubungan dengan IMS pada WPS di klinik VCT mobile Puskesmas Sukaraja dengan $p$ value $(p=0,002$ dan $\mathrm{OR}=7.7$ ).

ABK disebut sebagai komunitas highrisk men atau laki-laki dengan risiko tinggi terkena penyakit IMS karena mereka adalah laki-laki dengan mobilitas pekerjaan yang tinggi, tempat bekerja yang tidak menetap karena mengikuti rute perjalanan kapal yang kadang berlangsung dalam waktu yang lama. Hasil survey pendahuluan dilakukan kepada kepada 2 ABK, dari hasil survey tersebut didapat bahwa ABK kurang pengetahuan terkait penggunaan alat kontrasepsi, sehingga ABK dapat terkena infeksi penyakit menular seperti AIDS/HIV, sedangkan sikap $A B K$ terkait penggunaan alat kontrasepsi kurangnya sikap terhadap penyakit yang diderita, saat berhubungan intim tidak menggunakan kondom dan tindakan 
ABK setelah melakukan hubungan intim, tidak mencuci alat kelaminnya sehingga mudah terinfeksi menular seksual.

Tujuan penelitian ini adalah untuk mengetahui hubungan pengetahuan dan sikap dengan tindakan pencegahan penyakit infeksi menular seksual pada anak buah kapal di Pelabuhan Belawan 2018.

\section{METODE PENELITIAN}

Penelitian ini merupakan jenis penelitian yang menggunakan survey analitik. Rancangan penelitian yang digunakan adalah cross sectional suatu penelitian untuk mempelajari dinamika korelasi antara faktor-faktor risiko dengan efek, dengan cara pendekatan, observasi atau pengumpulan da suatu penelitian untuk mempelajari dinamika korelasi antara faktor-faktor risiko dengan efek, dengan cara pendekatan, observasi atau pengumpulan data sekaligus pada suatu saat (point time approach) Notoadmodjo (2010). Bertujuan untuk mengetahui hubungan pengetahuan dan sikap serta tindakan pencegahan penyakit IMS pada ABK di Pelabuhan Belawan, Tahun 2018.

$$
\text { Populasi adalah keseluruhan }
$$
subjek penelitian atau objek yang diteliti (Notoadmodjo, 2012). Populasi dalam penelitian ini adalah semua $A B K$ yang bersandar di Pelabuhan Belawan jumlah orang pada tahun 2018. Menurut Sugiyono (2016) teknik sampling adalah teknik pengambilan sampel. Untuk menentukan sampel yang akan digunakan dalam penelitian, tedapat berbagai teknik sampling yang digunakan. Adapun penelitian ini menggunakan rumus Slovin karena dalam penarikan sampel, jumlahnya harus representative agar hasil penelitian dapat digeneralisasikan dan perhitungannya pun tidak memerlukan tabel jumlah sampel, namun dapat dilakukan dengan rumus dan perhitungan sederhana. Rumus Slovin untuk menentukan sampel adalah sebagai berikut :

$$
\mathrm{n}=\frac{\mathrm{N}}{1+\mathrm{N}(\mathrm{e})^{2}}
$$

Keterangan:

$\mathrm{n}=$ Ukuran sampel/jumlah responden

$\mathrm{N}=$ Ukuran populasi

$\mathrm{e}=$ Presentase kelonggaran ketelitian kesalahan pengambilan sampel yang masih bisa ditolerir; $\mathrm{e}=0,1$

$$
\begin{aligned}
& \mathrm{n}=\frac{254}{1+254(0,1)^{2}} \\
& \mathrm{n}=\frac{254}{3,54}
\end{aligned}
$$$$
\mathrm{n}=\quad 71,75 \quad \text { dibulatkan } \quad 72
$$

responden.

Berdasarkan perhitungan diatas diperoleh sampel 71,75 dibulatkan menjadi 72 jumlah ABK. Pengambilan sampel dalam penelitian ini dengan teknik Stratified Random Sampling yaitu metode pengambilan sampel dimana populasi dibagi-bagi dalam strata (Riyanto,2015).

Penelitian ini dilakukan pada bulan Juli 2019. Pengumpulan data dalam penelitian dilakukan dengan wawancara dengan menggunakan alat bantu kuesioner. Uji Satistik pada analisis data menggunakan Uji Chi Square $\left(\mathrm{X}^{2}\right)$ dengan tingkat kepercayaan 95\% menggunakan program SPSS.

\section{HASIL PENELITIAN}

Deskripsi Karakteristik Responden

Tabel 1 Distribusi Frekuensi Karakteristik Responden Berdasarkan Umur, Status, Pendidikan dan Masa Kerja pada ABK di Pelabuhan Belawan Tahun 2019 
Jurnal Kebidanan Kestra (JKK), e-ISSN 2655-0822

Vol. 2 No.1 Edisi Mei-Oktober 2019

http://ejournal.medistra.ac.id/index.php/JKK

Received: 04 September 2019 :: Accepted: 26 September 2019:: Publish: 31 Oktober 2019

\begin{tabular}{lrr}
\hline \multicolumn{1}{c}{\begin{tabular}{c} 
Karakteristik \\
\multicolumn{1}{c}{ Responden }
\end{tabular}} & $\mathbf{n}$ & \% \\
\hline Umur : & 11 & 15,3 \\
$<30$ tahun & 38 & 52,8 \\
$30-50$ tahun & 23 & 31,9 \\
$>50$ tahun & & \\
\hline Status : & 28 & 38,9 \\
Belum Menikah & 44 & 61,1 \\
Menikah & & \\
\hline Pendidikan: & 25 & 34,7 \\
SMA & 37 & 51,4 \\
Diploma & 10 & 13,9 \\
Sarjana & & \\
\hline Masa Kerja : & 26 & 36,1 \\
$\leq 1$ tahun & 38 & 52,8 \\
1 - 3 tahun & 8 & 11,1 \\
$>3$ tahun & & \\
\hline
\end{tabular}

Berdasarkan tabel 1 diatas diketahui bahwa umur mayoritas tesponden adalah $30-50$ tahun sebanyak 38 orang $(52,8 \%)$, status mayoritas responden adalah menikah sebanyak 44 orang (61,1\%), pendidikan mayoritas responden adalah Diploma sebanyak 37 orang $(51,4 \%)$ dan masa kerja mayoritas responden adalah 1 - 3 tahun sebanyak 38 orang (52,8\%).

\section{Analisa Univariat}

Tabel 2 Distribusi Frekuensi Variabel Penelitian Berdasarkan Pengetahuan, Sikap, dan Tindakan Pencegahan Penyakit Menular pada ABK di Pelabuhan Belawan Tahun 2019

\begin{tabular}{|c|c|c|}
\hline Variabel Penelitian & $\mathbf{n}$ & $\%$ \\
\hline \multicolumn{3}{|l|}{ Pengetahuan : } \\
\hline Baik & 38 & 67,9 \\
\hline Kurang Baik & 34 & 32,1 \\
\hline Jumlah & 72 & 100 \\
\hline \multicolumn{3}{|l|}{ Sikap : } \\
\hline Positif & 33 & 45,8 \\
\hline Negatif & 39 & 54,2 \\
\hline Jumlah & 72 & 100 \\
\hline \multicolumn{3}{|l|}{ Tindakan : } \\
\hline Baik & 42 & 48,6 \\
\hline Kurang baik & 30 & 51,4 \\
\hline Jumlah & 72 & 100 \\
\hline
\end{tabular}

diketahui bahwa mayoritas responden berpengetahuan baik sebanyak 38 orang $(52,8 \%)$, mayoritas responden bersikap negatif sebanyak 39 orang $(54,2 \%)$, dan mayoritas tindakan responden baik dalam pencegahan penyakit infeksi menular seksual sebanyak 42 orang $(48,6 \%)$

\section{Analisis Bivariat}

Tabel 3 Hubungan Pengetahuan dan Sikap Dengan Tindakan Pencegahan Penyakit Infeksi Menular Seksual pada ABK di Pelabuhan Belawan Tahun 2019

\begin{tabular}{|c|c|c|c|c|c|c|c|}
\hline \multirow{3}{*}{$\begin{array}{c}\text { Variab } \\
\text { el }\end{array}$} & \multicolumn{4}{|c|}{$\begin{array}{c}\text { Tindakan } \\
\text { Pencegahan IMS }\end{array}$} & \multirow{2}{*}{\multicolumn{2}{|c|}{ Jumlah }} & \multirow{3}{*}{$\begin{array}{c}\text { Nil } \\
\text { ai } \\
p\end{array}$} \\
\hline & \multicolumn{2}{|c|}{ Baik } & \multicolumn{2}{|c|}{$\begin{array}{l}\text { Kurang } \\
\text { Baik }\end{array}$} & & & \\
\hline & $\mathbf{n}$ & $\%$ & $\mathbf{n}$ & $\%$ & $\mathbf{n}$ & $\%$ & \\
\hline \multicolumn{8}{|l|}{$\begin{array}{l}\text { Penget } \\
\text { ahuan }\end{array}$} \\
\hline Baik & 29 & $\begin{array}{c}76, \\
3\end{array}$ & 9 & $\begin{array}{c}23 \\
7\end{array}$ & 38 & 100 & $\begin{array}{l}0,0 \\
02\end{array}$ \\
\hline $\begin{array}{l}\text { Kurang } \\
\text { Baik }\end{array}$ & 13 & $\begin{array}{c}38, \\
2\end{array}$ & 21 & $\begin{array}{c}61 \\
8\end{array}$ & 34 & 100 & \\
\hline \multicolumn{8}{|l|}{ Sikap } \\
\hline Positif & 28 & $\begin{array}{c}84 \\
8\end{array}$ & 5 & $\begin{array}{c}15, \\
2\end{array}$ & 33 & 100 & $\begin{array}{l}0, \\
00\end{array}$ \\
\hline Negatif & 14 & $\begin{array}{c}35, \\
9\end{array}$ & 25 & $\begin{array}{c}64, \\
1\end{array}$ & 39 & 100 & 0 \\
\hline
\end{tabular}

Hasil uji statistic diketahui bahwa nilai $p=0,002<0,050$ yang berarti ada ubungan yang antara pengetahuan dengan dengan tindakan pencegahan penyakit infeksi menular seksual pada ABK di Pelabuhan Belawan Tahun 2018.

Hasil uji statistik diketahui bahwa nilai $p=0,000<0,050$ yang berarti ada hubungan sikap dengan tindakan pencegahan penyakit infeksi menular seksual pada ABK di Pelabuhan Belawan Tahun 2019.

\section{4. pembahasan}

Hubungan Pengetahuan Dengan Tindakan Pencegahan Penyakit 
Infeksi Menular Seksual pada ABK di Pelabuhan Belawan Tahun 2019

Berdasarkan hasil uji chi-square diperoleh nilai $p=0,002<0,050$, yang berarti bahwaada hubungan pengetahuan dengan tindakan pencegahan penyakit infeksimenular seksual pada ABK di Pelabuhan Belawan Tahun 2018.

Hasil penelitian ini sejalan dengan penelitian Sari (2015), diperoleh bahwa pengetahuan memiliki pengaruh terhadap perilaku pencegahan PMS. Nilai beta menunjukkan tanda positif menunjukkan semakin baik pengetahuan $A B K$ tentang penyakit menular seksual semakin baik pula perilaku pencegahan $A B K$ terhadap penyakit menular seksual.

Notoatmodjo

mendefinisikan bahwa pengetahuan adalah hasil dari tahu dan ini terjadi setelah orang melakukan penginderaan terhadap suatu objek tertentu. Penginderaan terjadi melalui panca indera manusia, yakni indera penglihatan, pendengaran, penciuman, rasa danraba.Sebagian besar pengetahuan manusia diperoleh melalui mata dan telinga.

Peningkatan pengetahuan dapat diperoleh melalui pendidikan kesehatan yang merupakan suatu kegiatan atau usaha untuk menyampaikan pesan kesehatan kepada masyarakat, kelompok dan individu dengan harapan bahwa individu dapat memperoleh pengetahuan kesehatan yang lebih baik. Peningkatan pengetahuan melalui pendidikan kesehatan akan menghasilkan perubahan atau peningkatan pengetahuan masyarakat. Akhirnya pengetahuan tersebut diharapkan berpengaruh terhadap perilakunya (Notoatmodjo, 2010).

Berdasarkan hasil penelitian yang dilakukan diperoleh bahwa dari $52,8 \%$ responden yang berpengetahuan baik, sebanyak 40,3\% diantaranya melakukan tindakan yang baik dalam pencegahan IMS. Sedangkan dari $47,2 \%$ yang berpengetahuan kurang, sebanyak $29,2 \%$ diantarnya melakukan tindakan yang kurang baik dalam pencegahan IMS. Hal ini mengindikasikan bahwa semakin baik tingkat pengetahuan yang dimiliki ABK, akan semakin meningkatkan kesadaran $A B K$ untuk melakukan tindakan pencegahan PMS, diantaranya seperti menggunakan kondom saat berhubungan seksual dengan yang bukan pasangannya, menghindarkan diri dari segala sesuatu yang menyebabkan tertular PMS, senantiasa memeriksakan kondisi kesehatan, melakukan pengobatan jika terindikasi menderita PMS.

\section{Hubungan SikapDenganTindakan Pencegahan Penyakit Infeksi Menular Seksual pada ABK di Pelabuhan Belawan Tahun 2018}

Berdasarkan hasil uji chi-square diperoleh nilai $p=0,000<0,050$, yang berarti bahwa ada hubungan sikap dengantindakan pencegahan penyakit infeksimenular seksual pada $A B K$ di Pelabuhan Belawan Tahun 2018.

Hasil penelitian ini sejalan dengan penelitian Rahamayani (2014), diperoleh bahwa pengetahuan memiliki pengaruh terhadap tindakan pencegahan PMS ( $p$ value $=0,048<$ $0,05)$. Kondisi tersebut menunjukkan sikap positif $A B K$ dalam menanggapi tindakan pencegahan PMS.

Menurut Arianidan Hargono dalam Tamp (2013), sikap sangat berkaitan erat dengan tingkat pengetahuan suatu individu. Sikap seseorang terhadap suatu objek menunjukkan tingkat pengetahuan orang tersebut terhadap suatu objek. Berdasarkan teori adaptasi apabila tingkat pengetahuan baik dapat 
mendorong suatu individu memiliki perilaku yang baik.

Sikap merupakan hal yang penting bukan hanya karena sikap itu sulit untuk diubah, tetapi karena sikap sangat mempengaruhi pemikiran social individu meskipun sikap tidak selalu direfleksikan dalam tingkah laku yang tampak dan juga karena sikap seringkali mempengaruhi tingkah laku individu terutama terjadi saat sikap yang dimiliki kuat dan mantap (Tamp, 2013)

Berdasarkan hasil penelitian yang dilakukan diperoleh bahwa dari $45,8 \%$ responden yang bersikap positif, sebanyak $38,9 \%$ diantaranya melakukan tindakan yang baik dalam pencegahan IMS. Sedangkan dari $54,2 \%$ yang bersikap negatif, sebanyak $34,7 \%$ diantarnya melakukan tindakan yang kurang baik dalam pencegahan IMS. Hal ini mengindikasikan bahwa sikap negatif ABK dalam upaya pencegahan PMS akan menyebabkan ABK kurang melakukan upaya tindakan dalam pencegahan PMS, diantaranya seperti tidak menggunakan kondom saat berhubungan seksual dengan yang bukan pasangannya, tidak pergi ke pelayanan kesehatan saat merasakan adanya gejala-gejala IMS, dan malas memeriksakan kondisi kesehatan setiap kapal sandar/berlabuh, kurangnya keinginan untuk menambah informasi tentang IMS sehingga menyebabkan kurangnya pengetahuan $\mathrm{ABK}$ tentang IMS.

\section{KESIMPULAN DAN SARAN}

Faktor yang berhubungan tindakan pencegahan penyakit infeksi menular seksual pada abk di pelabuhan belawan adalah pengetahuan dan sikap responden.

Saran Penliti kepada para ABK diharapkan untuk meningkatkan pengetahuan dan perhatiannya mengenai penyakit infeksi menular seksual yakni dengan mengikuti penyuluhan dari tenaga kesehatan, membaca buku dan majalah yang berkaitan dengan penyakit infeksi menular seksual. Kepada petugas kesehatan diharapkan memberikan penyuluhan kepada para $A B K$ saat melakukan pemeriksaan kesehatan ketika kapal bersandar/berlabuh, juga dengan membagikan brosur maupun leaflet kepada para ABK sebagai bahan bacaan yang dapat menambah pengetahuan sehingga dapat dijadikan informasi dalam upaya tinakan pencegahan penyakit infeksi menular seksual.

\section{UCAPAN TERIMA KASIH}

Peneliti mengucapkan terima kasih kepada semua pihak yang telah banyak memberikan bantuan dan dukungan serta ucapan terima kasih kepada bapak / ibu kepala Dinas Kesehatan Kota Medan dan UPT Puskemas Padang Bulan.

\section{DAFTAR PUSTAKA}

Amiruddin R. dkk. Determinan Sosial dan Perilaku Seksual Berisiko terhadap Penyakit Infeksi Menular Seksual, HIV dan AIDS pada Anak Jalanan di Kota Makassar Indonesia [Disertasi].Makassar : FKM Universitas Hasanuddin; 2012

Arikunto, S. 2013. Prosedur Penelitian Suatu Pendekatan Praktik. Jakarta :Rhineka Cipta.

Azwar, S. 2011. Sikap dan Perilaku Dalam: Sikap Manusia Teori dan Pengukurannya ed. Yogyakarta: Pustaka Pelajar.

Daili, Sjaiful Fahmii. dkk. Infeksi Infeksi Menular. Jakarta: FKUI, 2017.

David Tamp. (2013). Hubungan Pengetahuan, Sikap dengan 
Tindakan Pencegahan HIV/AIDS padaSiswa SMA Manado International School. Jurnal Kedokteran Komunitas dan Tropik: Volume 1 Nomor 4 Desember 2013

Departemen Kesehatan RI. 2008. Pedoman Pelaksanaan Kegiatan KIE Kesehatan Reproduksi untuk Petugas Kesehatan di Tingkat Pelayanan Dasar. Jakarta: Departemen Ksehatan RI.

Department of Health and Human Services Centers for Disease Control and Prevention.Sexually Transmitted Diseases Treatment Guidelines, 2010. MMWR Recomm Rep. 2010; 59 (12): 90-5

Djuanda A., et al, 2008. Ilmu Penyakit Kulit Dan Kelamin. Edisi Kelima. Jakarta: Balai Penerbit FKUI.

Goldman, L., \&Ausielo, D. 2008. Cecil Medicine (23rd ed.). Philadelphia Elsevier

Hutapea Ronald. Aids \& IMS dan Perkosaan.Jakarta: Rineka Cipta, 2017.

Kementerian Kesehatan. 2014. Profil Pengendalian Penyakitdan Penanggulangan Lingkungan Tahun 2013. Jakarta: Kementrian Kesehatan

Mubarak. W. I. 2011. Promosi Kesehatan. Jogyakarta : Graha ilmu

Nari, Jois. 2015. Analisis Faktor-Faktor yang Berhubungan dengan Kejadian IMS pada Remaja di Klinik IMS Puskesmas Rijali dan Passo Kota Ambon. Volume 10, No. 2, Agustus 2015

Nia Sari, Nur Cholis (2015), Faktor Faktor Yang Perilaku Pencegahan Penyakit Menular Seksual Pada anak Buah Kapal (Abk) Di Pelabuhan Tanjung Tembaga Probolinggo. Jurnal.
STIKes Surya Mitra Husada Kediri

Notoatmodjo S. Konsep Perilaku dan Perilaku Kesehatan. Jakarta:

Fakultas Kedokteran Universitas Indonesia; 2016.

Notoatmodjo, Soekidjo, (2010). IImu Perilaku Kesehatan: Rineka Cipta

Puspita, Linda. 2017, Analisis Faktor Yang Berhubungan Dengan Kejadian Infeksi Menular Seksual Pada Wanita Pekerja Seksual Analisis Faktor Yang Berhubungan Dengan Kejadian Infeksi Menular Seksual. Jurnal Ilmu Kesehatan 2 (1) 2017, 31-44.

Sugiyono. 2016. Metode Penelitian Kuantitatif, Kualitatif dan R\&D. Alfabteha: Bandung.

WHO. 2015. Sexually Transmitted Infections (STI's). [update 2016]:

Available from : http://www. who.int/mediacentre/ factsheets/fs110 /en/. 